\title{
Immunomodulatory Effects of Eurya emarginata on NC/Nga Mice as Models for Atopic Dermatitis
}

\author{
Seungheon Lee* \\ Department of Aquatic Biomedical Sciences, School of Marine Biomedical Sciences, College of Ocean Science, Jeju National University, \\ Jeju 690-756, Korea
}

Received February 14, 2014 /Revised April 7, 2014 /Accepted April 21, 2014

\begin{abstract}
In this study, a test for the immunity control effect by ethanolic extract of Eurya emarginata (EE-70E) on $\mathrm{NC} / \mathrm{Nga}$ mice as the models for atopic dermatitis was conducted with the following results. Atopic dermatitis in NC/Nga mice was induced by repeated application of 1-chloro-2,4-dinitrobenzene (DNCB) for 5 weeks. Mice were orally administered EE-70E or terfenadine, positive control for 3 weeks. Scratching behavior, clinical skin severity, and the levels of IL-4, L-13, IL-17, total serum IgG1, and total serum IgE were measured. The oral administration with EE-70E doses of 200 or $400 \mathrm{mg} / \mathrm{kg}$ significantly decreased scratching behavior scores and clinical skin severity score in a dose-dependent manner $(p<0.05)$. The administration of EE-70E at $400 \mathrm{mg} / \mathrm{kg}$ significantly decreased cytokines within the blood serum, that is, IL-4, L-13, and IL-17 compared to the control group $(p<0.05)$. The level of blood histamine was statistically significantly decreased. Administration of EE-70E at $400 \mathrm{mg} / \mathrm{kg}$ significantly decreased the levels of total serum IgE $(p<0.05)$. The above results indicated that EE-70E was effective in improving the symptoms of atopic dermatitis through various immunity control mechanisms.
\end{abstract}

Key words : Atopic dermatitis, clinical skin severity, Eurya emarginata, IgE, scratching behavior

\section{서 론}

아토피 피부염은 가려움증을 동반하는 만성 재발성 습진 질환으로 알레르기 비염, 기관지 천식으로 이어지는 이른바 아토피 행진의 시작이 될 수 있는 질환이다. 현재까지 정확한 원인과 발병기전이 밝혀져 있지는 않으나 유전적인 소인, 환경적 요인, 심리적 요인, 면역학적 요인 및 피부장벽기능 이상이 중요한 원인 및 기전으로 제시되고 있다 $[6,12]$.

$\mathrm{NC} / \mathrm{Nga}$ 마우스는 자발적으로 아토피 양 피부염이 발생하 는 동물 모델로 1997년 Matsuda 등에 의해 보고 되었으며, 보통의 환경(conventional circumstance)에서 사육하며 특별 한 항원 접촉 없이도 아토피 피부염과 유사한 피부 병변이 발생하며 혈청 $\mathrm{IgE}$ 의 생성이 증가됨이 발견되었다[18]. 그러나 $\mathrm{NC} / \mathrm{Nga}$ 마우스는 항원이 존재하지 않는 무균 환경(specific pathogen-free, $\mathrm{SPF}$ )에서는 피부 병변이 자연적으로 발생하지 않으며, 보통의 환경(conventional circumstance)에서 사육해 도 자발적으로 병변이 나타나지 않는 경우가 많다[18]. 이 경

\footnotetext{
*Corresponding author

Tel : +82-64-754-3476, Fax : +82-64-756-3493

E-mail : slee76@jejunu.ac.kr

This is an Open-Access article distributed under the terms of the Creative Commons Attribution Non-Commercial License (http://creativecommons.org/licenses/by-nc/3.0) which permits unrestricted non-commercial use, distribution, and reproduction in any medium, provided the original work is properly cited
}

우, 2,4-dinitrothlorobenzene (DNCB), 2,4-dinitrofluorobenzene, 2,4,6-trinitrothlorobenzene 등의 화학적 항원을 이용하면 아 토피 양 피부병변을 발생시킬 수 있는데, 이렇게 화학적 항원 으로 피부염을 유발시킨 모델이 현재까지 많은 연구자들의 아토피 피부염에 관련한 실험적 연구에 이용되고 있다[30, 32]. 지금까지 병인으로 알려진 것에는 면역학적으로 $\mathrm{T}$ 림프구의 활성화, 랑게르한스선의 세포의 자극 증가, 사이토카인의 체 계의 이상, 세포 매개성 면역의 감소, $\mathrm{IgE}$ 의 증가 등이 있으며 그밖에 혈관 작용성 매개체의 분비와 약리학적인 반응의 변형 도 아토피성 피부염의 병리상태에 중요한 역할을 한다고 보고 되고 있다[34]. 피부염 진행 과정에 침윤되는 염증세포들은 주 로 대식세포, 호산구와 같은 속발반응에 관여하는 세포들이며 이들은 아토피성 피부염의 급성기에 존재하던 세포들에서 생 성된 IL-1 과 TNF- $a$ 와 같은 사이토카인의 직접적인 영향으로 피부에 침투한 것으로 여겨지고 있다[13]. 또한, 아토피성 피부 염 환자의 $80 \%$ 에서 $\mathrm{IgE}$ 의 혈청치 증가가 보고됨으로써 이 질 환이 면역학적 이상과 관련이 있다는 증거를 제시하고 있다 [27]. $\mathrm{IgE}$ 의 증감은 병변의 범위와 증상의 중증도와 관련이 있 음을 시사하고 있고, 면역학적인 기전이 관여한다는 것은 알 려져 있지만 정확한 병인에 관해서는 아직까지 이해가 부족한 실정이다. 아토피성 피부염은 전체인구의 약 $10 ~ 20 \%$ 에게서 발병하고 있는 것으로 추산되고 있으나 완치시킬 수 있는 뚜 렷한 치료법이 없는 실정이다[29].

우묵사스레피(Eurya emarginata)는 차나무과(Theaceae)에 속 하는 상록관목으로 섬쥐똥나무 또는 개사스레피나무라고도 
불린다. 주로 우리나라의 제주도와 경상남도 - 전라남도의 해 안산지, 일본, 대만, 중국, 인도 등지에 자생한다. 주로 관상용 정원수로 쓰이고, 민간에서는 잎을 거담제나 이뇨제로 사용한 다[23]. Morita 등[22]은 우묵사스레피에서 chrysoeriol, hyperin, quercitrin을 분리하였다고 보고한 바 있고, 그 외 우묵사스 레피 잎에서 quercitirin, eutigoside $B$ 및 eutigoside $C$ 를 분리 하여 전골수 백혈병 환자에서 유래된 HL-60 세포조에서 세포 증식이 억제되었음을 확인하였다 $[25,26]$. 또한 발표한 eutigoside B 와 eutigoside C를 TNF- $a$, IL-6, IL-6 $\beta$ 등의 pro-inflammatory 사이토카인의 생성억제, iNOS의 발현 및 COX-2 의 생성 억제효과가 있음을 보고하였다[14]. 이후 chrysoeriol, apigenin, (2R, 3R)-3,5,7,3', $5^{\prime}$-pentahydroxyflavan, quercitrin, hyperin, quryanoside, euryamaside를 분리하여 항산화 활성 을 보고하였다[24].

본 연구에서는 비교적 자원이 풍부하면서도 그 식물 화학적 성분 및 생리활성에 대한 연구가 미비한 우묵사스레피를 선택 하여 $\mathrm{DNCB}$ 로 피부염을 유발한 $\mathrm{NC} / \mathrm{Nga}$ 마우스에 대상으로 가려움증 판정 시험, $\mathrm{Total} \mathrm{IgE}$, 사이토카인의 농도측정 및 관 능 검사를 시행하였으며 이 결과를 통해 우묵사스레피 추출물 의 면역학적 작용 및 아토피 피부염 모텔에 관하여 고찰한 바를 보고하고자 한다.

\section{재료 및 방법}

\section{시료}

본 실험에 사용한 우묵사스레피는 2012년 9월 제주도 서귀 포시 위미리에서 채취하였으며 정확히 감정한 후 실험에 사용 하였고, 그 기준 표본은 제주대학교 해양과학대학 수산약리학 실험실에 보관하였다(JJUHMP-12-06). 우묵사스레피 추출물 (EE-70E)은 원생약을 증류수로 2회 세척한 뒤 원생약의 10 배 의 $70 \% \mathrm{EtOH}$ 수용액을 가하고 2회 중탕가열하여 추출하였다. 추출이 완료된 다음 Whatman (No. 1) 여과지로 여과하고, 이 를 rotary evaporator로 감압 농축하여 얻은 점조상의 추출물 을 동결 건조기(Eyela, model FDU-2000, Japan)에서 건조한 뒤 얻어진 분말을 실험에 사용하였다(수득률 $17.43 \%$ ).

\section{실험동물}

본 실험에는 중앙실험동물에서 구입한 웅성의 $\mathrm{NC} / \mathrm{Nga}$ mousen $(20 \sim 25 \mathrm{~g})$ 를 사용하였으며, 모든 동물은 일정한 온도 $\left(25 \pm 2^{\circ} \mathrm{C}\right)$ 와 습도 $(50 \pm 5 \%)$ 가 유지되며 12 시간의 명암주기 $(7: 30$ A.M. - 7:30 P.M.)가 조절되는 동물실에서 사육되었다. 또한 동물들은 동물실에서 1주일 동안 안정 후 7-9개의 그룹으로 임의로 분리되었고, 전 실험기간 동안 식이와 물을 제한 없이 섭취하였다. 실험동물의 취급은 실험동물윤리위원회에 계획 서를 제출하고 승인받았으며(승인번호 2013-307), 위원회의 동물실험 취급 규정에 따라 사육하고 실험하였다.

\section{아토피 피부염 유발}

DNCB (2,4-dinitrochlorobenzen, Sigma, USA)를 acetone 과 olive oil 이 3:1로 혼합된 용액에 $1 \%$ 로 희석시켰다. 대조군 과 실험군의 모든 NC/Nga 마우스 복강내에 졸레틸(zoletil)을 주사하여 마취시킨 후 등 부위를 면도기를 이용하여 제모하였 다. 제모 2 일째 $1 \% \mathrm{DNCB} 200 \mu 1$ 를 도포하여 1차 감작 시키고 2 일 후 재도포하여 2차 감작 시켰다. 다시 acetone과 olive oil 이 3:1로 혼합된 용액을 용매로 하여 $0.4 \% \mathrm{DNCB}$ 용액을 만들 었다. 3 차감작부터는 $0.4 \% \mathrm{DNCB}$ 용액을 $150 \mu \mathrm{l}$ 씩 도포하였다. 2 차감작 4 일 후, 3 차 감작을 시작하여 이후 4 주간 주 3 회씩 감 작하여 총 5 주간 아토피 피부염을 유발하였다. 5 주간의 감작 으로 아토피 피부염이 유발된 이후 총 21 일간 약물을 투여하 였으며 투약 기간 동안 주 3회의 항원감작을 유지하였다.

\section{약물 투여}

아토피 피부염 유발 시작 5주 후부터 약물을 50-400 mg/ $\mathrm{kg}$ 의 용량으로 $10 \%(\mathrm{v} / \mathrm{v} \%)$ Tween80 수용액에 현탁시켜 실 험군에는 마우스 체중 $1 \mathrm{~kg}$ 당 $10 \mathrm{ml}$ 이 투여되도록 매일 1 회 총 21일간 경구투여하였다. 양성 대조군에는 terfenadine을 5 $\mathrm{mg} / \mathrm{kg}$ 의 용량으로 $10 \%(\mathrm{v} / \mathrm{v} \%)$ Tween 80 수용액에 현탁시켜 매일 1회 총 21일간 경구투여하였다. 대조군에는 같은 부피의 $10 \%$ (v / v\%) Tween80 수용액을 경구투여하였다.

\section{가려움증 판정 시험}

약물 투여 종료 후 실험동물의 가려움증 판정 시험을 위하 여 $0.4 \% \mathrm{DNCB}$ 용액 $150 \mu 1$ 를 도포한 후 30분을 방치하고 이후 30 분 동안 긁는 모습을 관찰하였다. 실험 동물은 개체 별로 격리하여 관찰하였으며 각 마우스가 몇 번을 긁는지 횟수를 세었다. 2 초 이상 길게 이어지는 연속동작은 $\mathrm{n}$ 초간 지속된 경 우 $\mathrm{n}$ 회로 세었고 2 초 내의 짧은 동작은 각각 1 회로 세었다.

\section{혈청 내 면역글로불린 및 사이토카인 농도 측정}

Scratching behavior 관찰을 실험 종료 후 dimethyl ether로 마취한 상태에서 심장 천자법을 이용하여 채혈한 다음 6,500 $\mathrm{rpm}$ 에서 20 분간 원심 분리하여 혈청을 분리하였다. IL-4, IL-13, IL-17, histamine농도는 ELISA kit를 이용하여 다음과 같이 측정하였다. 각 well에 혈청을 $50 \mu 1$ 씩 분주하고 biotin-conjugated antibody를 $50 \mu \mathrm{l}$ 씩 가하여 혼합한 후 2시간 동안 $37^{\circ} \mathrm{C}$ 에서 반응시키고 washing buffer를 이용하여 4 회 세 척하였다. 이를 다시 $100 \mu \mathrm{ll}$ 의 streptavidin-HRP Working solution을 가하여 30 분 동안 실온에서 반응시킨 후 washing buffer를 이용하여 4회 세척하였다. $100 \mu 1$ 의 stabilized chromogen을 가하여 암소에서 30 분간 방치한 후 $100 \mu 1$ 의 stop 용액 을 처리하고 ELISA reader로 $450 \mathrm{~nm}$ 에서 흡광도를 측정하였 다.

$\mathrm{IgG1}$ 과 IgE 생성량의 측정은 ELISA kit를 이용하여 다음과 
같이 측정하였다. 항체를 coating 완충 용액에 희석하여 microwell에 coating한 후 $4^{\circ} \mathrm{C}$ 에서 overnight 하였다. 각 well을 3 회 washing 완충 용액으로 세척한 후 혈청(100배 희석)을 100 ul씩 분주하였다. 이를 1 시간 동안 실온에서 방치하고 washing 완충 용액으로 2회 세척한 다음, avidin-HRP conjugated antibody $100 \mu 1$ 를 처리하고 1시간 실온에서 방치한 후 다시 세척하였다. 여기에 TMB 기질을 $100 \mu 1$ 씩 분주하고 암소에서 30 분간 방치한 다음 $50 \mu \mathrm{l}$ 의 stop 용액을 처리한 후 Microplate reader (Molecular Device, USA)로 파장 450-570 nm에서 optical density를 측정하였다.

\section{관능 평가}

약물 처리 후 3 주 때 아토피성 피부염에서 일반적으로 사용 되는 임상적 육안 평가법으로 관능평가를 실시하였다. 평가 항목은 홍반(Erythema), 가려움과 건조 피부(Pruritus \& Dry skin), 부종과 혈종(Edema \& Hematoma), 짓무름(Excoriation), 태선화(Lichenification)로 5 가지이다. 각각의 항목은 없음(0), 약함(1), 중증도(2), 심함(3)으로 채점하였다.

\section{통계 처리}

모든 데이터는 mean \pm S.E.M.으로 표현하였으며, 일원배치 분산분석(one-way ANOVA)을 한 후 $p<0.05$ 수준에서 StudentNewman-Keuls test를 이용하여 각 실험군 평균치 간의 유의 성을 검정하였다.

\section{결 과}

\section{가려움증 판정 시험}

$\mathrm{DNCB}$ 를 도포하여 자극한 후 30 분간 긁는 횟수를 관찰한 결과, Fig. 1 와 같이 $\mathrm{DNCB}$ 처리만 한 대조군에서 222.7 \pm 17.2 희 의 긁는 행동이 관찰되었다. 그러나 EE-70E의 200과 $400 \mathrm{mg}$ / $\mathrm{kg}$ 의 투여군에서 $\mathrm{DNCB}$ 에 의해 유도되는 긁는 회수가 각각 $164.2 \pm 16.5$ 와 $142.2 \pm 19.1$ 회로 용량의존적으로 유의성 있게 감 소하였다( $p<0.05$, Fig.1).

\section{혈청 내 면역글로불린 및 사이토카인 농도}

$\mathrm{EE}-70 \mathrm{E}$ 의 투여군에서의 혈청 내 사이토카인 생성량에 미치 는 영향을 알아보기 위해 혈청 내 사이토카인은 IL-4, L-13,

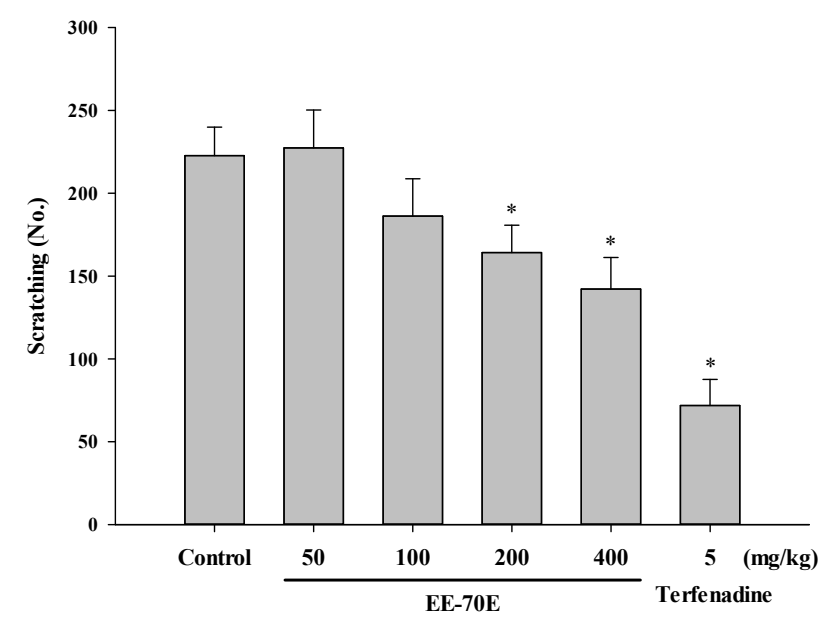

Fig. 1. Effects of EE-70E on scratching behavior in NC/Nga mice $(n=7 \sim 8)$. Each bar represents the mean \pm S.E.M. of scratching counts for 30 minutes. EE-70E $(50-400 \mathrm{mg} / \mathrm{kg}$, p.o.) was administrated for 3 weeks $\left({ }^{*} p<0.05\right.$ versus control group).

IL-17의 생성량을 측정한 결과 IL-4, L-13, IL-17에서 EE-70E $400 \mathrm{mg} / \mathrm{kg}$ 투여군이 각각 $186.2 \pm 22.5 \mathrm{pg} / \mathrm{ml}, 297.5 \pm 43.1$ $\mathrm{pg} / \mathrm{ml}, 577.8 \pm 37.1 \mathrm{pg} / \mathrm{ml}$ 로 나타나 대조군에 비해 모두 감소 하였다. 이는 EE-70E의 $400 \mathrm{mg} / \mathrm{kg}$ 투여가 혈청 내 사이토카 인 생성량을 감소시켜 염증을 억제시키는데 영향을 주는 것으 로 나타났다( $p<0.05, \mathrm{Tab} .1)$. 또한 histamine은 IgE가 비만세포 를 자극하여 염증물질과 함께 방출되는 것으로 알려져 있는 데, 이번 실험에서 EE-70E $400 \mathrm{mg} / \mathrm{kg}$ 투여군은 $82.2 \pm 6.3$ $\mathrm{ng} / \mathrm{ml}$ 로 나타나, 대조군의 $103.5 \pm 8.9 \mathrm{ng} / \mathrm{ml}$ 와 비교하여 유의 성 있게 감소한 것으로 나타났다 $(p<0.05$ Tab.1).

또한 본 연구에서 혈청 내 면역글로불린 생성량에 미치는 영향을 조사한 결과, $\mathrm{IgG1}$ 의 생성량이 대조군, $4.1 \pm 0.5 \mu \mathrm{g} / \mathrm{\mu l}$ 에 비해 EE-70E 투여군은 $3.9 \pm 0.4 \mu \mathrm{g} / \mu \mathrm{l}$ 로 다소 감소하는 경향 을 보였으나 유의성 있는 결과는 관찰되지 않았다(Fig. 2A). 그러나 Fig. $2 \mathrm{~B}$ 에서 보는 바와 같이 아토피성 피부염이 유발된 마우스에게 $\mathrm{EE}-70 \mathrm{E}$ 를 3주간 처치한 결과, $\mathrm{IgE}$ 함량은 대조군 $(29.1 \pm 5.5 \mathrm{ng} / \mathrm{\mu l})$ 과 비교하여 EE-70E $400 \mathrm{mg} / \mathrm{kg}$ 투여군 $(19.1 \pm 3.9 \mathrm{ng} / \mathrm{\mu l}, p<0.05)$ 및 terfenadine 투여군 $(13.3 \pm 3.7 \mathrm{ng} / \mathrm{\mu l}$, $p \times 0.05)$ 로 유의성 있는 감소가 관찰되었다.

Table 1. Effects of EE-70E on levels of blood IL-4, IL-13, IL-17 and histamine in NC/Nga mice

\begin{tabular}{ccccc}
\hline & IL-4 $(\mathrm{pg} / \mathrm{ml})$ & IL-13 $(\mathrm{pg} / \mathrm{ml})$ & IL-17 $(\mathrm{pg} / \mathrm{ml})$ & Hitamine $(\mathrm{ng} / \mathrm{ml})$ \\
\hline Normal & $122.7 \pm 17.2$ & $218.7 \pm 10.1$ & $237.7 \pm 20.1$ & $38.1 \pm 7.1$ \\
Control & $227.4 \pm 22.8^{\#}$ & $387.4 \pm 17.8^{\#}$ & $697.4 \pm 77.8^{\#}$ & $103 . .^{\#}$ \\
EE-70E & $186.2 \pm 22.5^{*}$ & $297.5 \pm 43.1^{*}$ & $577.8 \pm 37.1^{*}$ & $82.2^{*} \pm 6.3^{*}$ \\
Terfenadine & $124.2 \pm 16.5^{*}$ & $280.2 \pm 20.5^{*}$ & $410.2 \pm 50.5^{*}$ & $75.1 \pm 5.1^{*}$ \\
\hline
\end{tabular}

Animals were orally treated with EE-70E. Control animals were treated with the same volume of $10 \%$ Tween 80 solution. Data are expressed as means \pm S.E.M. ( $\mathrm{n}=4$ / group, ${ }^{\#} p<0.05$ versus normal group, ${ }^{*} p<0.05$ versus control group). 

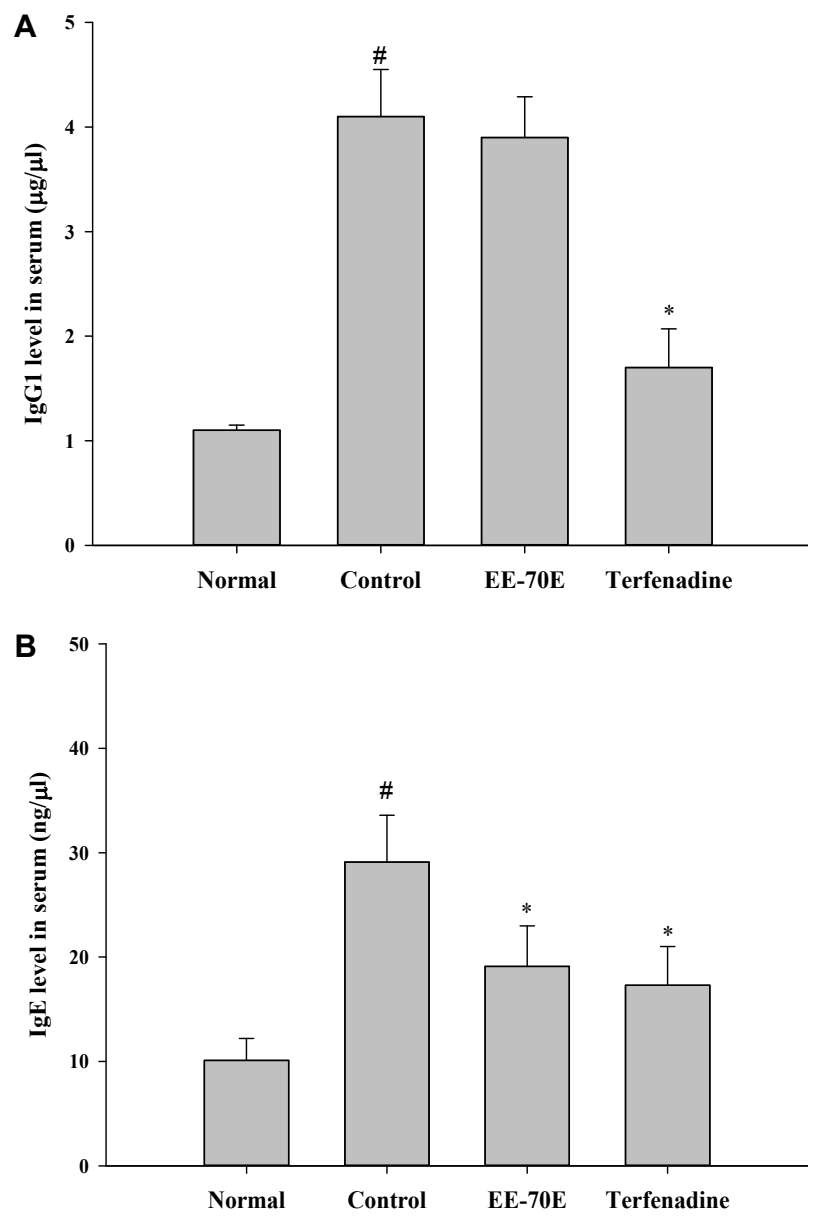

Fig. 2. Effects of EE-70E on levels of blood IgG1 and IgE in $\mathrm{NC} / \mathrm{Nga}$ mice $(n=4)$. Each bar represents the mean \pm S.E.M. of IgG1 (A) and IgE (B) levels in blood $\left({ }^{*} p<0.05\right.$ versus control group).

\section{관능 평가}

$\mathrm{NC} / \mathrm{Nga}$ 생쥐를 제모한 후 $\mathrm{TNCB}$ 를 5 주간 도포하여 피부 염을 유발시키면서 실험군인 EE-70E를 3주간 구강 투여하였 다. 피부염 지수는 아토피 피부염을 유발한 후 최종 3주 후에 피부염의 심화 정도를 관능적 방법에 의하여 측정하였다. 그 결과, 대조군은 $7.67 \pm 1.21$, EE-70E $200 \mathrm{mg} / \mathrm{kg}$ 투여군은 $4.53 \pm$ $1.32, \mathrm{EE}-70 \mathrm{E} 400 \mathrm{mg} / \mathrm{kg}$ 투여군은 $3.33 \pm 1.51$, 양성 대조군인 terfenadine 투여군은 $1.83 \pm 0.75$ 로 대조군과 비교하여 모두 유 의성 있는 감소를 나타내었다( $p \ll 0.05$, Fig. 3).

\section{고 찰}

피부는 외부환경과 체내의 경계를 이루면서 수많은 항원에 접촉할 기회를 갖는다. 아토피성 피부염이 발병하면 피부의 과민반응과 소양증에 대한 역치의 감소로 인해서 피부를 긁게 되고, 긁는 자극과 염증반응은 피부의 각질 세포에서 사이토 카인을 분비시켜[11] 염증 반응을 심화시키고, 각질층의 변형

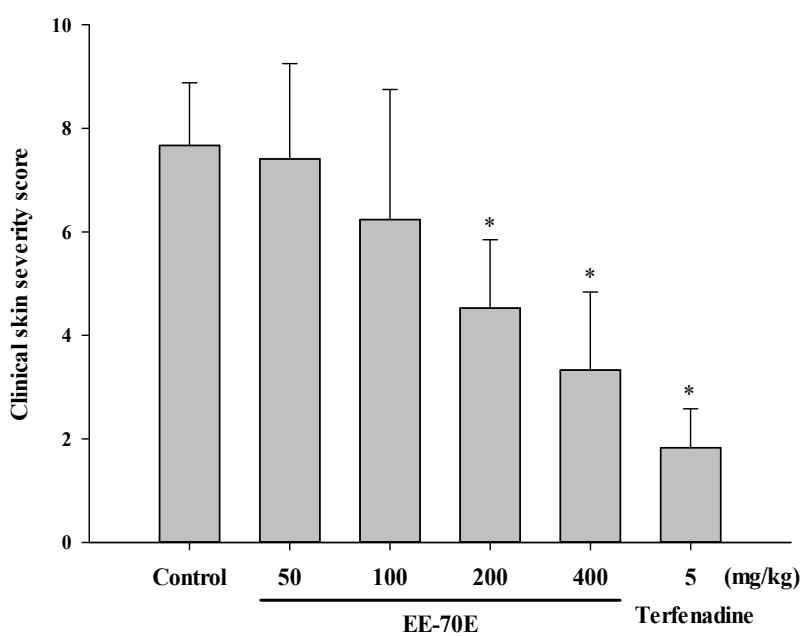

Fig. 3. Effects of EE-70E on severity score of atopic dermatitis in NC/Nga mice $(n=4)$. Each symbol represents the mean \pm S.E.M. of severity scores $\left({ }^{*} p<0.05\right.$ versus control group).

을 유도하며[8] 면역세포를 활성화시킨다. 면역세포의 활성화 는 $\operatorname{IgE}$ 생성증가와 항체 반응 증가를 유도하고 $\operatorname{IgE}$ 의존성 histamine 유리체의 활동성을 증가시켜 histamine분비를 촉진 시킨다[3]. Histamine등은 호산구의 침윤을 유도하고[5], 급성 과민반응과 소양감을 유발한다[28]. 이러한 과정에 나타나는 피부소양감, 피부 변형(홍반, 건조피부, 부종과 혈종, 짓무름, 그리고 태선화) 정도와 혈청 중 사이토카인 및 $\mathrm{IgE}$ 함량 등을 근거로 우묵사스레피 추출물의 아토피성 피부염 개선 효과를 평가하였다.

아토피치료제로는 주로 항히스타민 및 steroid 제제가 많이 쓰이고 있으나 부작용에 따른 안전성 문제가 심각하여 $[7,21]$, 최근에는 치료제로써 활용 가능한 천연소재에 관한 연구가 활발히 이루어지고 있다. 이에 본 연구에서는 동물모델에 EE$70 \mathrm{E}$ 를 경구 투여하여 효능 평가를 하기 위해 관능 검사와 scratching behavior를 측정하였으며 혈청 내 면역글로불린 및 사이토카인 농도를 측정 하였다. 그 결과, EE-70E 투여군이 대조군에 비해서, scratching behavior에서 EE-70E 투여에 의 해 긁는 횟수의 감소가 관찰되었다(Fig. 1). 뿐만 아니라 $\mathrm{EE}-70 \mathrm{E}$ 투여에 의해 $\mathrm{DNCB}$ 로 유도된 피부염 동물모델에서 대조군에 비해 혈청 사이토카인, 히스타민 및 $\mathrm{IgE}$ 의 농도를 감소시키고(Table 1, Fig. 2), 또한 피부염 유발정도가 현저하 게 개선시켰음을 관능 검사를 통하여 확인하였다(Fig. 3).

아토피의 면역학적 기전에는 Th1 / Th2 세포간의 불균형, Langerhans cell 활성증가, 사이토카인 체계이상 등이 제시되 고 있다[16, 19]. 특히 Th1, Th2 중 아토피 피부염은 Th2 반응에 치우친 면역반응으로 Th2에서 발현되는 사이토카인인 IL-4, IL-5, IL-10, L-13이 그것이다[17]. Th1에서 발현되는 사이토카 인은 IL-2, IFN- $\gamma$ 가 상대적으로 적어지면서 나타나는 인체 내 면역학적 불균형으로 발생한다[27]. 또한 Th17 세포가 생산하 
는 사이토카인 IL-17도 염증반응을 증가시키는 것으로 알려져 있다[2]. EE-70E 투여군에서의 혈청 내 사이토카인 생성량에 미치는 영향을 알아보기 위해 혈청 내 사이토카인은 IL-4, L-13, IL-17의 생성량을 측정한 결과 IL-4, L-13, IL-17에서 $\mathrm{EE}-70 \mathrm{E}$ 투여군에서 대조군과 비교하여 모두 감소하였다. 이는 EE-70E의 투여가 혈청 내 사이토카인 생성량을 감소시켜 염증 을 억제시키는데 영향을 주었을 것으로 사료된다. 특히 histamine은 $\mathrm{IgE}$ 가 비만세포를 자극하여 염증물질과 함께 방출되 는 것으로 알려져 있는데[10], 본 연구에서 EE-70E 투여에 의 해 histamine 유리의 감소를 통하여 염증을 억제시킬 것으로 추측된다.

Th2 세포들은 여러 사이토카인과 케모카인 같은 인자들을 생성하여 아토피 피부염 진행을 유도하는 것으로 알려져 있 다. 생성된 IL-4, IL-5, IL-6, IL-10, IL-13 같은 Th2 사이토카인 은 B림프구의 생성과 분화를 유도하고 비만세포와 호산구의 과민반응을 유도한다[1]. $\mathrm{IgE}$ 는 대부분의 아토피 피부염 환자 들에게서 발현되는 표식자 역할을 하는 immunoglobulin으로 써 B림프구에서 생성되고 비만세포 및 호산구와 호중구의 탈 과립화(degranulation)를 유발하여 히스타민과 같은 염증성 물질의 분비를 매개한다[6]. B림프구는 isotype switching을 유도하여 IgG1, IgE과 같은 immunoglobulin의 분비를 촉진시 켜 histamine 등의 화학매개체를 유리시킴으로써 피부의 염증 을 유발한다[33]. IgE 생산을 유도하고, IL-5를 생산하여 호산 구의 분화 증식 또는 활성화에 의해 만성형의 알레르기 반응 이 이루어진다 $[9,20]$. 또한 비만세포 표면상에 있는 고친화성 $\mathrm{IgE}$ 수용체 $(\mathrm{Fc} \varepsilon \mathrm{RI})$ 에 과발현된 $\mathrm{IgE}$ 가 결합하여 감작된 상태가 되고 그 상태에서 다시 항원에 노출되게 되면 비만세포를 활 성화시켜 histamine과 leukotriene 등의 화학전달물질과 IL-4, $\mathrm{IL}-5, \mathrm{TNF}-\mathrm{a}, \mathrm{GM}-\mathrm{SCF}$ 등의 사이토카인을 분비하여 과민반응 을 유발하게 된다[4]. 따라서 피부에 IL-4, IL-13 발현 여부는 아토피 피부염의 피부표면에서의 Th2 세포의 활성이 얼마나 잘 조절되고 있는지를 확인할 수 있게 하는 요소이다. 본 연구 에서는 혈청 내 면역글로불린 생성량에 미치는 영향을 확인한 결과, $\mathrm{IgE}$ 의 생성량은 대조군에 비해 $\mathrm{EE}-70 \mathrm{E}$ 투여군에서 용량 의존적으로 감소하였다(Fig. 2B). 이는 EE-70E 투여군에 의해 $\mathrm{IL}-4, \mathrm{~L}-13, \mathrm{IL}-17$ 의 분비를 억제하여 $\mathrm{IgE}$ 생산이 감소된 것으로 사료된다.

아토피성 피부염은 주로 유소아기에 발병이 시작하는 만성 재 발성 피부 질환으로 연령에 따라 임상 양상과 병변의 분포 차이를 나타내는데 유아에서는 두부와 신전부의 습진 양상을 보이고, 삼출이나 가피 형태의 급성 습진성 양상을 나타내나 소아기로 넘어가면서 전주와(antecubital area)와 슬와(popliteal area) 같은 굴측부의 병변이 뚜렷해지면서 건조증의 형태로 나타나는 경우가 많고, 사춘기와 성인에서는 간찰부위(intertriginous area), 목, 목의 양측의 태선화, 안면과 수부(hand area) 습진 등의 소견을 보이고 양진과 태선화가 관찰된다 $[15$,
31]. 본 연구에서는 아토피성피부염이 유발된 등 부위의 증상 을 주로 관찰하여 평가하였다. 본 연구에서 $\mathrm{DNCB}$ 로 아토피 피부염을 유도한 NC/Nga 마우스 모델에 EE-70E를 투여하고 육안으로 관찰하였을 때 상당한 피부염의 개선 효과를 볼 수 있었다(Fig. 3). 이러한 개선 효과는 EE-70에 의한 사이토카인 의 분비가 억제되어 $\mathrm{IgE}$ 의 생산이 감소되고 염증 기전의 차단 에 의한 것으로 사료된다.

본 연구 결과는 EE-70E가 아토피성 피부염의 증상을 개선 하는 약물 또는 기능성 화장품 원료로 개발될 수 있음을 나타 내고 있다. 그러나 EE-70E의 아토피성 피부염 증상을 완화효 과가 우묵사스레피의 어떤 성분에 기인하는지는 확인되지 않 았다. 그러므로 향후 연구를 통하여 아토피성 피부염 치료 효 과가 어떤 성분에 기인하며 어떤 작용기전을 통하여 발현되는 지 밝혀야 할 것이다.

\section{감사의 글}

이 논문은 2013학년도 제주대학교 학술진흥연구비 지원사 업에 의하여 연구되었음

\section{References}

1. Aversa, G., Punnonen, J., Cocks, B. G., de Waal Malefyt, R., Vega, F., Jr. Zurawski, S. M., Zurawski, G. and de Vries, J. E. 1993. An interleukin 4 (IL-4) mutant protein inhibits both IL-4 or IL-13-induced human immunoglobulin G4 (IgG4) and IgE synthesis and B cell proliferation: support for a common component shared by IL-4 and IL-13 receptors. J Exp Med 178, 2213-2218.

2. Bedoya, S. K., Lam, B., Lau, K. and Larkin, J., 3rd. 2013. Th17 cells in immunity and autoimmunity. Clin Dev Immunol 2013, 1-16.

3. Budde, I. K., de Heer, P. G., Natter, S., Mahler, V., van der Zee, J. S., Valenta, R. and Aalberse, R. C. 2002. Studies on the association between immunoglobulin $\mathrm{E}$ autoreactivity and immunoglobulin E-dependent histamine-releasing factors. Immunology 107, 243-251.

4. Charles, N., Hardwick, D., Daugas, E., Illei, G. G. and Rivera, J. Basophils and the T helper 2 environment can promote the development of lupus nephritis. Nat Med 16, 701-707.

5. Cho, S. M., Kim, M. E., Kim, J. Y., Park, J. C. and Nahm, D. H. Clinical efficacy of autologous plasma therapy for atopic dermatitis. Dermatology 228, 71-77.

6. Choi, Y., Kim, M. S. and Hwang, J. K. 2012. Inhibitory effects of panduratin $\mathrm{A}$ on allergy-related mediator production in rat basophilic leukemia mast cells. Inflammation 35, 19041915.

7. Correale, C. E., Walker, C., Murphy, L. and Craig, T. J. 1999. Atopic dermatitis: a review of diagnosis and treatment. $\mathrm{Am}$ Fam Physician 60, 1191-1198, 1209-1110.

8. Deing, V., Roggenkamp, D., Kuhnl, J., Gruschka, A., Stab, 
F., Wenck, H., Burkle, A. and Neufang, G. 2013. Oxytocin modulates proliferation and stress responses of human skin cells: implications for atopic dermatitis. Exp Dermatol 22, 399-405.

9. Fölster-Holst, R., Pape, M., Buss, Y. L., Christophers, E. and Weichenthal, M. 2006. Low prevalence of the intrinsic form of atopic dermatitis among adult patients. Allergy 61, 629632.

10. Frandsen, P. M., Krohn, I. J., Hoffmann, H. J. and Schiotz, P. O. The Influence of $\operatorname{IgE}$ on cultured human mast cells. Allergy Asthma Immunol Res 5, 409-414.

11. Ikezawa, Y., Nakazawa, M., Tamura, C., Takahashi, K., Minami, M. and Ikezawa, Z. 2005. Cyclophosphamide decreases the number, percentage and the function of CD25+ $\mathrm{CD} 4+$ regulatory $\mathrm{T}$ cells, which suppress induction of contact hypersensitivity. J Dermatol Sci 39, 105-112.

12. Kwon, A. H., Qiu, Z. and Hirao, Y. 2007. Topical application of plasma fibronectin in full-thickness skin wound healing in rats. Exp Biol Med (Maywood) 232, 935-941.

13. Lee, H., Han, A. R., Kim, Y., Choi, S. H., Ko, E., Lee, N. Y., Jeong, J. H., Kim, S. H. and Bae, H. 2009. A new compound, $1 \mathrm{H}, 8 \mathrm{H}$-pyrano $[3,4-\mathrm{c}]$ pyran-1,8-dione, suppresses airway epithelial cell inflammatory responses in a murine model of asthma. Int J Immunopathol Pharmacol 22, 591-603.

14. Lee, H. J., Oh, T. H., Yoon, W. J., Kang, G. J., Yang, E. J., Park, S. S., Lee, N. H., Kang, H. K. and Yoo, E. S. 2008. Eutigoside $\mathrm{C}$ inhibits the production of inflammatory mediators (NO, PGE(2), IL-6) by down-regulating NF-kappaB and MAP kinase activity in LPS-stimulated RAW 264.7 cells. J Pharm Pharmacol 60, 917-924.

15. Leung, D. Y., Hirsch, R. L., Schneider, L., Moody, C., Takaoka, R., Li, S. H., Meyerson, L. A., Mariam, S. G., Goldstein, G. and Hanifin, J. M. 1990. Thymopentin therapy reduces the clinical severity of atopic dermatitis. J Allergy Clin Immunol 85, 927-933.

16. Lugovic, L., Lipozencic, J. and Jakic-Razumovic, J. 2005. Prominent involvement of activated Th1-subset of T-cells and increased expression of receptor for IFN-gamma on keratinocytes in atopic dermatitis acute skin lesions. Int Arch Allergy Immunol 137, 125-133.

17. Masuoka, M., Shiraishi, H., Ohta, S., Suzuki, S., Arima, K., Aoki, S., Toda, S., Inagaki, N., Kurihara, Y., Hayashida, S., Takeuchi, S., Koike, K., Ono, J., Noshiro, H., Furue, M., Conway, S. J., Narisawa, Y. and Izuhara, K. Periostin promotes chronic allergic inflammation in response to Th2 cytokines. J Clin Invest 122, 2590-2600.

18. Matsuda, H., Watanabe, N., Geba, G. P., Sperl, J., Tsudzuki, M., Hiroi, J., Matsumoto, M., Ushio, H., Saito, S., Askenase, P. W. and Ra, C. 1997. Development of atopic dermatitis-like skin lesion with IgE hyperproduction in NC/Nga mice. Int Immunol 9, 461-466.

19. Matsui, K. and Nishikawa, A. 2013. Peptidoglycan-induced $\mathrm{T}$ helper 2 immune response in mice involves interleukin-10 secretion from langerhans cells. Microbiol Immunol 57, 130138.
20. Meyer, P., Co Minh, H. B. and Demoly, P. 2004. [A revised nomenclature for allergy]. Arch Pediatr 11, 1131-1134.

21. Mihara, K., Kuratani, K., Matsui, T., Nakamura, M. and Yokota, K. 2004. Vital role of the itch-scratch response in development of spontaneous dermatitis in NC/Nga mice. Br J Dermatol 151, 335-345.

22. Morita, N., Shimizu, M., Arisawa, M., Koshi, M. and Kubo, Y. 1974. [Studies on medical resources. XXXIV. The constituents of genus Eurya. (1). E. japonica Thunb. and E. emarginata Makino (author's transl)]. Yakugaku Zasshi 94, 872-874.

23. Oh, S., Lee, J. H., Ko, K. S., Shin, D. B. and Koh, S. C. 2010. Antioxidative activity, including inhibitory activities of $\mathrm{ACE}, \mathrm{APN}$ and a-amylase, in theaceae plants native to Jeju Island. Korean J Plant Res 23, 406-414.

24. Oh, T. H., Baik, J. S., Yoo, E. S., Kang, H. K. and Lee, N. H. 2011. New phenylpropanoid glycosides from Eurya emarginata (Thunb.) Makino. Bull Korean Chem Soc 32, 3175-3178.

25. Park, S. Y., Yang, H. C., Moon, J. Y., Lee, N. H., Kim, S. J., Kang, J. H., Lee, Y. K., Park, D. B., Yoo, E. S. and Kang, H. K. 2004. Induction of the apoptosis of HL-60 promyelocytic leukemia cells by Eurya emarginata. Cancer Lett 205, 31-38.

26. Park, S. Y., Yang, H. C., Moon, J. Y., Lee, N. H., Kim, S. J., Kang, J. H., Lee, Y. K., Park, D. B., Yoo, E. S. and Kang, H. K. 2005. The cytotoxicity of eutigosides from Eurya emarginata against HL-60 promyelocytic leukemia cells. Arch Pharm Res 28, 1047-1052.

27. Schiller, M., Metze, D., Luger, T. A., Grabbe, S. and Gunzer, M. 2006. Immune response modifiers-mode of action. Exp Dermatol 15, 331-341.

28. Schroeder, J. T. 2011. Basophils: emerging roles in the pathogenesis of allergic disease. Immunol Rev 242, 144-160.

29. Simonsen, A. B., Deleuran, M., Johansen, J. D. and Sommerlund, M. 2011. Contact allergy and allergic contact dermatitis in children - a review of current data. Contact Dermatitis 65, 254-265.

30. Sung, Y. Y., Yang, W. K., Lee, A. Y., Kim, D. S., Nho, K. J., Kim, Y. S. and Kim, H. K. 2012. Topical application of an ethanol extract prepared from illicium verum suppresses atopic dermatitis in NC/Nga mice. J Ethnopharmacol 144, 151-159.

31. Suzuki, R., Shimizu, T., Kudo, T., Ohtsuka, Y., Yamashiro, Y. and Oshida, K. 2002. Effects of n-3 polyunsaturated fatty acids on dermatitis in NC/Nga mice. Prostaglandins Leukot Essent Fatty Acids 66, 435-440.

32. Takeda, K. and Gelfand, E. W. 2009. Mouse models of allergic diseases. Curr Opin Immunol 21, 660-665.

33. Till, S. J., Francis, J. N., Nouri-Aria, K. and Durham, S. R. 2004. Mechanisms of immunotherapy. I Allergy Clin Immunol 113, 1025-1034.

34. Yamaguchi, J., Nakamura, F., Aihara, M., Yamashita, N., Usui, H., Hida, T., Takei, K., Nagashima, Y., Ikezawa, Z. and Goshima, Y. 2008. Semaphorin3A alleviates skin lesions and scratching behavior in NC/Nga mice, an atopic dermatitis model. J Invest Dermatol 128, 2842-2849. 


\section{초록 : 아토피 피부염의 동물 모델인 NC/Nga Mice에서의 우묵사스레피의 면역조절 효과}

이 승 헌

(제주대학교 해양과학대학 해양생명과학과)

본 연구에서는 1-chloro-2,4-dinitrobenzene (DNCB)로 유도한 아토피 피부염 동물 모델인 NC/Nga mice에 대 한 Eurya emarginata 에탄올 추출물(EE-70E)의 면역 조절 효능을 확인하고자 하였다. $\mathrm{DNCB}$ 를 5 주간 도포하여 유 도한 아토피 동물 모델인 NC/Nga mice에 EE-70E를 3주간 경구 투여한 후 scratching behavior 및 clinical skin severity score, 혈청 면역지표(IL-4, IL-13, IL-17, histamine, IgG1, IgE)의 농도를 측정하였다. DNCB를 도포하여 3 주동안 경구 투여한 결과, EE-70E의 200 및 $400 \mathrm{mg} / \mathrm{kg}$ 용량에서 clinical skin severity의 감소, scratching behavior의 감소 및 혈중 IL-4 및 IL-13, IL-17, histamine, IgE의 농도가 대조군과 비교하여 유의성 있게 농도의존적으로 감소하는 결과가 관찰되었다 $(p<0.05)$. EE-70E의 경구투여는 NC/Nga mice 아토피 피부염 동물모델에서 면역조

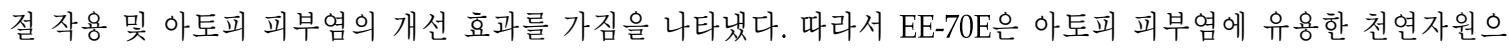
로서 기대된다. 